Integrated Reporting and Corporate Performance: Empirical Evidence of The IIRC Framework Adoption by Muhammad Wildan Affan

\title{
Integrated Reporting and Corporate Performance: Empirical Evidence of The IIRC Framework Adoption
}

\author{
Muhammad Wildan Affan *)
}

\begin{abstract}
Sustainability and transparency issues are becoming trending in the nature of corporate reporting. Stakeholders are accused to bring together all financial and nonfinancial metrics into one integrated report. The purpose of this study is to determine the effect of integrated reporting toward corporate performance. Integrated reporting measurement uses the construct adopted from IIRC. The research sample in this study is basic and chemical industry sector that listed in the Indonesia Stock Exchange in 2017. The reason in choosing those industries as a research subject is because the basic and chemical industry sector is recorded as a high growth industry sector in 2017. This study uses a linear regression as an analysis tool. This study concluded that integrated reporting has significant effect toward corporate performance.
\end{abstract}

Keywords: Integrated Reporting; Corporate Performance; IIRC; Financial Information; NonFinancial Information

\section{INTRODUCTION}

\subsection{Research Background}

Industrial development which has reached industry 4.0, forces business actors to accelerate the production flow by using technological advancements. The use of technology that requires large costs which have an impact on the demand for quality financial statements produced by companies. It is characterized by low information asymmetry between agents as parties who have information and principals as parties who need information. Good quality of financial statements will affect investment efficiency (Lambert, Leuz, \& Verrecchia, 2007). Therefore, investment efficiency can eliminate the impact of industrial developments that require high costs.

Furthermore, information asymmetry can be minimized by delivering information both in terms of financial and non-financial. Since the Lehman Brother bankruptcy in 2008 triggered the global economic crisis, information users need information that presents the overall picture of the company in terms of both financial and non-financial aspects in an integrated manner in order to increase the value of the company both short and long term. This is reinforced by (Fanani, 2009) who stated that financial information and non-financial information could not be separated in terms of business decision making by investors. This information problem was responded to by the IIRC by developing a new reporting model in 2011 named integrated reporting. The IR framework aims to provide a link between organizational strategy, governance, financial performance and CSR in the company's economic activities to help capital providers to find out how companies shape short, medium and long term values that are very useful for decision making (Soyka, 2013).

Currently, the IR framework is not a mandatory reporting framework for companies of various countries, due to regional differences that greatly influence the decision to use IRs in disclosing company activities (Rivera-Arrubla, Zorio-Grima, \& García-Benau, 2017). Companies in Indonesia are still conducting a report with the IR, but only in terms of voluntary, but the mean reporting done has reached 50\% of the required elements (Kustiani, 2017). This voluntary disclosure aims to account for the manager's activities towards shareholders, which will have an impact on the sustainability of the company itself by increasing shareholder trust. Apart from the 
statement above, there are questions about the benefits of integrated reporting for companies and stakeholders.

\subsection{Research Problem}

Based on the research background, the problem of this study is does integrated integrated reporting framework has an impact toward corporate performance?

\subsection{Research Purpose}

This study aims to find out how the impact of the company's voluntary efforts in disclosing financial statements using an integrated reporting framework on company performance.

\section{THEORETICAL FRAMEWORK AND HYPOTHESES DEVELOPMENT}

\subsection{The Effect of Integrated Reporting Toward Corporate Performance}

It is the manager's responsibility to expanse the presentation of company information from time to time to fulfill the need of stakeholders of relevant information in decision making. To this decade, the International Integrated Reporting Council has produced a framework called integrated reporting to answer all information needs that can describe short-term and long-term corporate sustainability.

Based on agency theory, managers and shareholders will act in accordance with their interests. The actions taken by managers are more directed towards moral hazard actions due to the information asymmetry possessed. (Scott, 2015) stated that information asymmetry is the difference in information obtained by each party that is concerned with a business transaction. For this reason, managers must make disclosures that can eliminate information asymmetry (Verrecchia, 2001). The integrated reporting element consists of several elements that must be fulfilled to give an idea of the extent of the information disclosure provided. Where these elements are presented in an integrated manner to be able to minimize information asymmetry between managers and stakeholders and are a response to the desire for transparency reporting to build public trust (Krzus, 2011)

Furthermore, integrated reporting that conducts disclosures by combining financial and nonfinancial elements of the company can reduce agency problems and information asymmetry by encouraging managers to make decisions by prioritizing stakeholder strategies (Martinez, 2016). The materiality contained in IR disclosure changes managers' perceptions of the power of stakeholders (Mitchell, Agle, \& Wood, 1997). This loss of agency and asymmetry problems causes managers to focus on increasing future cash flows (Kramer \& Porter, 2011)

Declining levels of information asymmetry and manager's perceptions as a result of disclosure of financial statements with the integrated reporting framework increase stakeholder confidence in predicting the future value of companies. Stakeholder trust can be in the form of investment and cooperation (Sejati \& Prastiwi, 2015). Increased investment and cooperation indirectly will increase company profits, which can be said as an increase in company performance. Therefore, the hypothesis proposed in this study is;

$\mathrm{H}_{1}$ : Integrated reporting disclosure has a positive effect on corporate performance.

\section{RESEARCH METHOD}

\subsection{Research Design}

The corporate performance in this study was proxied by the level of profitability. Corporate profitability can be measured by the company's ability to obtain profits based on assets owned. This research was measured profitability with Return on Assets, which is the ratio of after-tax income to overall assets. The size used to calculate Return on Assets was: 
Return on Asset $(\mathrm{ROA})=\frac{\text { Net Income After Tax }}{\text { Total Asset }} \times 100 \%$

Meanwhile, the integrated reporting in this study defined as the level of disclosure of financial statements that meet the elements of integrated reporting. Measurement of integrated reporting elements was based on 55 questions/constructs adopted from the criteria of the International Integrated Reporting Council (IIRC). Each question is measured using a dummy scale by giving a value of 1 if the financial statements answer or there are elements in accordance with the question/construct and a value of 0 if the financial statements do not answer, or there are no elements in accordance with the question/construct. The results of the dummy scale were calculated by summing the values obtained and divided by the number of questions/constructs available to determine the value of integrated reporting.

Integrated Reporting Index $=\sum_{i-n}^{1} \frac{x_{i}}{N}$

\subsection{Population and Sample}

The population of this study was all basic and chemical industry companies listed on the Indonesia Stock Exchange (IDX) as of December 31, 2017. This is based on the fact that basic and chemistry industry sector recorded high growth in 2017. The sampling technique was done by purposive sampling with the criteria for companies that have made an Initial Public Offering (IPO) in 2017 and have presented annual reports. This study only used secondary data from IDX to measure integrated reporting and corporate performance, therefore, the validity and reliability test is not needed in this study.

\subsection{Research Framework}

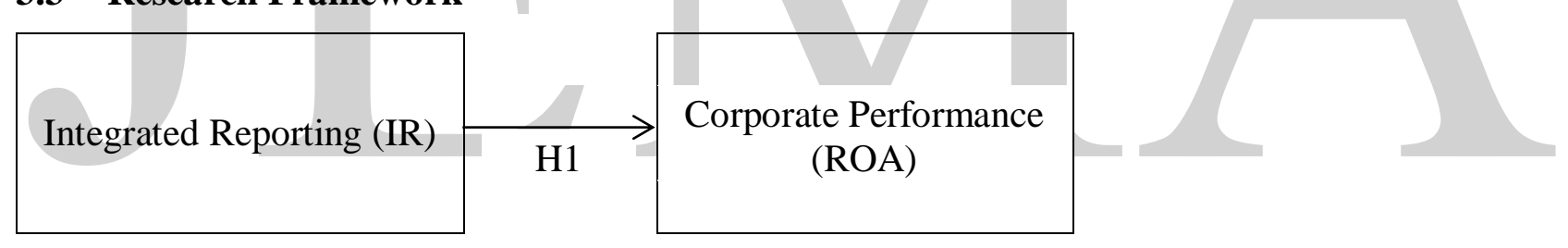

Picture 1 Research Framework

\section{RESEARCH RESULT AND ANALYSIS}

\subsection{Descriptive Analysis}

Table 1 Descriptive Data

\begin{tabular}{|l|c|c|c|c|}
\hline \multicolumn{1}{|c|}{ Variables } & $\mathrm{N}$ & Minimum & Maximum & Mean \\
\hline Integrated Reporting & 58 & 0,35 & 0,93 & 0,5878 \\
\hline Corporate Performance (ROA) & 58 & $-0,19$ & $.0,22$ & 0,0220 \\
\hline
\end{tabular}

Source: Primary Data Processed, 2018

Table 1 shows that the integrated reporting variables have a minimum value of 0,35 and a maximum value of 0,93 , with an average value of 0,59 . This indicates that the level of disclosure of integrated reporting elements that consist of financial and non-financial metrics is quite high, although there is no obligation to disclosure it from government regulation. Furthermore, a corporate performance which measured by return on assets (ROA) shows that ROA has a minimum value of $-0,19$ and a maximum value of 0,22 with an average value of 0,02 . This indicates that there is corporate that experience losses so that the ratio of profits to assets owned is quite low. 
JEMA: Jurnal Ilmiah Bidang Akuntansi dan Manajemen, Vol. 16 No. 2 (2019)

http://riset.unisma.ac.id/index.php/jema (e-ISSN : 2597-4071)

\subsection{Validity and Reliability}

This study only used secondary data from IDX to investigate the effect of integrated reporting on corporate performance, therefore, the validity and reliability test is not needed in this study.

\subsection{Research Analysis}

In order to get the best-fit regression equation, the data analysis must fulfill the following classic assumptions:

a. Multicollinearity

Based on the VIF calculation results, it can be seen that the variables of entrepreneurial behavior, organizational innovation, and organizational competence have a VIF value $<5$, thus it can be concluded that the regression model does not have a multicollinearity problem..

\section{b. Autocorrelation}

Based on the calculation results, it can be seen that the value of the Durbin-Watson test is 1,994 so that it is greater than $1,480(\mathrm{dU})$ and smaller than 1,689 (4-dU). It means there is no autocorrelation in the regression model.

c. Heteroscedasticity

Based on the scatterplot test result, it shows that scattered points without patterns (random) both below and above the number 0 on the $\mathrm{Y}$-axis. Therefore, it concluded that there are no symptoms of heteroscedastiscity from this regression model.

d. Normality

Based on the results of the Kolmogorov Smirnov Test (KST), the significance value of the variable is $0,200(>0,05)$. This shows that the variable of integrated reporting and corporate performance are normally distributed.

Tabel 2 Regression Result

\begin{tabular}{|c|c|c|c|c|}
\hline Variable & $\begin{array}{l}\text { Regression } \\
\text { Coefficient }\end{array}$ & $\mathrm{T}_{\text {test }}$ & Sig. & Decision \\
\hline Integrated Reporting - IR (X) & $-0,036$ & 2,118 & 0,039 & Significant \\
\hline Constant & \multicolumn{4}{|c|}{0,020} \\
\hline $\mathrm{R}$ & \multicolumn{4}{|c|}{0,272} \\
\hline R square & \multicolumn{4}{|c|}{0,074} \\
\hline Adjusted R square & \multicolumn{4}{|c|}{0,058} \\
\hline $\mathrm{F}_{\text {test }}$ & \multicolumn{4}{|c|}{4,485} \\
\hline Sig. F & \multicolumn{4}{|c|}{0,039} \\
\hline $\mathrm{N}$ & \multicolumn{4}{|c|}{58} \\
\hline F table & \multicolumn{4}{|c|}{3,161} \\
\hline t table & \multicolumn{4}{|c|}{1,671} \\
\hline Dependent Variable & \multicolumn{4}{|c|}{ Corporate Performance - ROA (Y) } \\
\hline
\end{tabular}

Source: Primary Data Processed, 2018

Table 2 shows the regression model formed as follows

$\mathrm{ROA}=-0,036+0,099 \mathrm{IR}$

Table 2 also shows that the integrated reporting variable had a significance effect toward corporate performance because it has probability value that below $0,05(0,039)$ with a t-count is greater than ttable $(2,118>1,671)$. This result is reinforced by Martinez (2016) that integrated reporting is positively related to market value and estimated future cash flows. This relationship is inseparable 
from the performance carried out by managers due to changes in managers' perceptions in carrying out business strategies that refer to increasing shareholder value. So the more companies are willing to adopt the integrated reporting framework, the more improved company performance will be.

\subsection{Research Discussion}

The results of the regression analysis in this study indicate that integrated reporting has a positive effect toward company performance. This result support Musleh Alsartawi (2018) and Churet \& Eccles (2014) argument that states there is a positive association between online financial disclosure and firm performance. Hastuti (2005) added that the more information provided by a private company in their integrated report, the better corporate performance will get. But SingletonGreen \& Hodgkinson (2013) guided that to some extent the effort to disclosure financial and narrative reporting will overlap with the problems of financial reporting itself. This is because, to a significantly greater extent than for financial reporting, there are often multiple authorities able to impose non-financial disclosure requirements in reporting to shareholders.

\section{RESEARCH CONCLUSION AND LIMITATION}

\subsection{Conclusion}

This study aimed to determine the effect of integrated reporting disclosure on company performance in basic and chemical industry sectors in 2017. The results showed that the distribution of integrated reporting disclosure data conducted by sample companies was quite high even though there were no regulations that required disclosure. This is inseparable from the manager's awareness of the impact of information asymmetry that can reduce stakeholder trust. Furthermore, the hypothesis test found a positive effect of integrated reporting toward corporate performance. The breadth of material expressed in the integrated reporting framework makes a strong relationship between stakeholders and managers resulting in the ability to read the opportunities and risks of each strategy taken, which will then automatically have an impact on the corporate's performance.

\subsection{Limitation}

The limitation of this study is the use of an integrated reporting framework that is not fully adopted, resulting in a low influence of integrated reporting on corporate performance. Therefore, further research is needed to investigate the effect of integrated reporting on financial performance in corporate that have fully adopted the integrated reporting framework.

\section{REFERENCES}

Churet, C., \& Eccles, R. G. (2014). Integrated reporting, quality of management, and financial performance. Journal of Applied Corporate Finance, 26(1), 56-64. https://doi.org/10.1111/jacf.12054.

Fanani, Z. (2009). Kualitas Pelaporan Keuangan: Berbagai Faktor Penentu dan Konsekuensi Ekonomis. Jurnal akuntansi dan keuangan Indonesia, 6(1), 20-45. http://dx.doi.org/10.21002/jaki.2009.02.

Hastuti, T. D. (2005). Hubungan antara Good Corporate Governance dan Struktur Kepemilikan dengan Kinerja Keuangan (Studi Kasus pada Perusahaan yang listing di Bursa Efek Jakarta). Simposium Nasional Akuntansi, 8, 238-247.

Kramer, M. R., \& Porter, M. (2011). Creating shared value. Harvard business review, 89(1/2), 6277. 
Krzus, M. P. (2011). Integrated reporting: if not now, when. Zeitschrift für internationale Rechnungslegung, 6, 271-276.

Kustiani, N. A. (2017). Penerapan elemen-elemen integrated reporting pada perusahaan yang terdaftar di bursa efek indonesia. INFO ARTHA, 3, 44-61.

Lambert, R., Leuz, C., \& Verrecchia, R. E. (2007). Accounting information, disclosure, and the cost of capital. Journal of accounting research, 45(2), 385-420. https://doi.org/10.1111/j.1475679X.2007.00238.x.

Martinez, C. (2016). Effects of Integrated Reporting on the Firm's Value: Evidence from Voluntary Adopters of the IIRC's Framework. Available at SSRN 2876145.

Mitchell, R. K., Agle, B. R., \& Wood, D. J. (1997). Toward a theory of stakeholder identification and salience: Defining the principle of who and what really counts. Academy of management review, 22(4), 853-886. https://doi.org/10.5465/amr.1997.9711022105.

Musleh Alsartawi, A. (2018). Online financial disclosure and firms' performance: Evidence from the Gulf Cooperation Council countries. World Journal of Entrepreneurship, Management and Sustainable Development, 14(2), 178-190. https://doi.org/10.1108/WJEMSD-11-2017-0082.

Rivera-Arrubla, Y. A., Zorio-Grima, A., \& García-Benau, M. A. (2017). Integrated reports: disclosure level and explanatory factors. Social Responsibility Journal, 13(1), 155-176. https://doi.org/10.1108/SRJ-02-2016-0033.

Scott, W. R. (2015). Financial Accounting Theory. Toronto: Pearson Prentice Hall.

Sejati, B. P., \& Prastiwi, A. (2015). Pengaruh Pengungkapan Sustainability Report terhadap Kinerja dan Nilai Perusahaan. Diponegoro Journal of Accounting, 195-206.

Singleton-Green, B., \& Hodgkinson, R. (2013). Financial Reporting Disclosures: Market and Regulatory Failures. Information for Better Markets series. http://dx.doi.org/10.2139/ssrn.2366877.

Soyka, P. A. (2013). The International Integrated Reporting Council (IIRC) integrated reporting framework: toward better sustainability reporting and (way) beyond. Environmental Quality Management, 23(2), 1-14. https://doi.org/10.1002/tqem.21357.

Verrecchia, R. E. (2001). Essays on disclosure. Journal of accounting and economics, 32(1-3), 97180. https://doi.org/10.1016/S0165-4101(01)00025-8.

*) Muhammad Wildan Affan, Department of Accounting, Muhammadiyah University of Malang, Malang, Indonesia (Email: wildan@umm.ac.id) 